\title{
THE CONVERGENCE TEST OF INDONESIA BANKING INEFFICIENCY: DO MACROECONOMIC INDICATORS MATTER?
}

\author{
Rudi Purwono', Mohammad Zeqi Yasin² \\ ${ }^{1}$ Faculty of Economics and Business, Airlangga University, Surabaya, Indonesia. \\ Email: rudipurwono@feb.unair.ac.id \\ ${ }^{2}$ Coordinating Ministry for Economic Affairs, Jakarta, Indonesia. \\ Email: zeqiyasin1@gmail.com
}

\begin{abstract}
This paper analyzes the inefficiency convergence of Indonesian banks using Stochastic Frontier Analysis and panel data estimation, covering the period after financial crisis 2008 until 2017. This paper also investigates the determinant of this inefficiency implying the convergence. To estimate the inefficiency rate, proxied by price of loan, this paper uses three inputs including price of labor, price capital, and price of fund. Our analysis shows that during 2008-2017 the inefficiency score converged at a speed of $26.2 \%$. Furthermore inflation, gross domestic product, and exchange rate significantly affect the growth of inefficiency convergence. This paper contributes to the empirical literatures particularly on banking research. Overall, the findings imply that policymakers can mitigate the effects of the global financial crisis by lowering interest rate, providing fiscal stimulus, as well as protecting the poorest from financial deterioration.
\end{abstract}

Keywords: Global crisis; Convergence; Inefficiency; Banking.

JEL Classification: E32.

\author{
Article history: \\ Received : March 10, 2018 \\ Revised : May 21, 2018 \\ Accepted : July 24, 2018 \\ Available online : July 31, 2018 \\ https://doi.org/10.21098/bemp.v21i1.946
}




\section{INTRODUCTION}

The Asian Financial Crisis (AFC) of 1998 and the Global Financial Crisis (GFC) of 2008 have had implications for Indonesia. They forced the banking industry to change in terms of structure to avoid company damages (Sufian and Habibullah, 2010). Following the AFC, Bank Indonesia-the country's central bank, declared that its foreign reserves were insufficient to boost the exchange rate which at that time had reached Rp 2.450 to the US dollar (Patten et al., 2001). Subsequently, by mid-1998, the exchange rate had weakened to Rp 14,900 to the US dollar. This calamity was exacerbated by the general collapse of financial prices in Southeast Asia (Cole and Slade, 1998). Banks, as the dominant financial institution, almost collapsed due to the unavailability of funds following excessive withdrawals. The high ratio of non-performing loans to total credit resulted due to the large volumes of lending (Basri, 2013). This led to panic, which affected foreign investors, resulting in massive capital outflows from Indonesia and indeed the region.

A decade after the AFC, there was the GFC, which was much larger than the AFC in terms of magnitude and scale. This crisis had several impacts on Indonesia; it weakened both the exchange rate and the stock market. The effect of a declining stock market was felt by the banking sector Banking sector credit growth, for instance, experienced a remarkable fall from $32 \%$ to $10 \%$ (Basri and Siregar, 2009).

Both crises prompted research on Indonesia's banking sector. This research saw several indicators used as performance indicators of the Indonesian banking sector. The most popular indicator has been efficiency. Zhang and Matthews (2012) postulate three reasons efficiency could appropriately measure economic performance in emerging countries, like Indonesia. First, the main process of financial intermediation of Indonesia is handled by banking system as debt and capital market remains immature and underdeveloped. It is evident that the banking system has a role in propagating a shock to the rest of the economy. Hence, scrutinizing the banking system is mandatory.

Secondly, the more strict competition among banking companies occurred in developing economies. Miller and Noulas (1996) contend that the question of the bank efficiency emerged in 1980s. This has roots to the 1980s shocks which led to banking failure and an upsurge in the bank merger activity. They postulate a moment in which the bank faced a stiffer competition in terms of market share implicating a further importance of the efficiency measurement, notably regarding their finding of inefficient banks which may not long survive.

Thirdly, the infiltration of the central bank policy will incredibly depends on the competitive construction and efficiency of the banking system. Moreover, the rapid growth of a financial technology directly regulated by the Financial Service Authority (Otoritas Jasa Keuangan, OJK) will significantly create dynamics of a banking sector depicted in the efficiency. Hence, it is important to measure the current efficiency performance of banks as an evaluation.

In the last decade, the calculation of efficiency has been developed to be not only analyzed partially but also by a way in which the entire banking can be accommodated and considered as a part of an evaluation. Farrell (1957) suggests that technical efficiency would measure proportionally the reduction of current input to produce predetermined outputs owned by an individual production unit. 
Subsequently, Fried et al. (1999) discover some reasons for efficiency related to the external operating environment. In the current research, the measurement of the efficiency, is directed towards the equity trend among the individual production unit called efficiency convergence, conducted by several researches, such as Casu and Molyneux (2003), Weill (2009), Casu and Girardone (2010), and Zhang and Matthews (2012). Nevertheless, it was discovered that the efficiency convergence in Indonesia is not prolific ${ }^{3}$, except in Zhang and Matthews (2012) where cost efficiency convergence was measured.

While recently more studies have emerged on Indonesia's banking sector efficiency, none have examined the efficiency convergence and its determinants. The study by Zhang and Matthews (2012) employs a two-stage semi-parametric double bootstrap Data Envelopment Analysis (DEA) method to estimate the cost efficiency from 1992 to 2007. They find evidence in which the general post-crisis structural reform process recovered the average level of efficiency and increased the distribution of efficiency across banks significantly. The AFC and the structural reform had the effect of slowing down the adjustment speed of bank efficiency. Other researches, such as Margono et al. (2010), which use the Stochastic Frontier Analysis (SFA), also investigate efficiency from a cost perspective of the Indonesian bank though they do not test convergence specifically.

However, the study of Hadad et al. (2011) estimates the technical efficiency in production perspective although they uses DEA and carry on to a Tobit regression analysis. They find that from 2003 to 2007, the Indonesian banking efficiency score ranged from $34 \%$ to $97 \%$. Subsequently, as the truncated regression resulted, the banks' efficiency scores had a significantly positive correlation with share prices and return on equity in all models, and with the log of total assets in the super efficiency analysis. Tobit regression in Hadad et al. (2011) study is actually functionally similar with the efficiency effect (TE) in SFA. Hence, the determinant of efficiency score in this result will be recognized as the TE effect variable.

The current paper answers several research questions. The first is what factors influence the rate of inefficiency of Indonesian banking?. We address this question by measuring the cost efficiency using SFA. Second, what is the pattern of its inefficiency score: is it converging or diverging? What is the speed of convergence? This question will be examined by a convergence test using the model of Barro and Sala-i-Martin (1992). Lastly, we also address the question of how macroeconomic indicators affect the inefficiency convergence, following the model proposed by Becerril-Torres et al. (2010).

The next section of this paper outlines the literature review. Section III explain the stochastic frontier analysis, the data, and empirical model. Section IV provide the estimation result and its analysis, while section $\mathrm{V}$ provide conclusion and will close the presentation of this paper.

To our knowledge, only Zhang et al. (2012) have tested the convergence efficiency of Indonesia. Other researches (see Olson and Zoubi, 2017) have mostly tested the efficiency convergence across countries, which includes Indonesia. 


\section{PREVIOUS STUDIES}

\subsection{Inefficiency and Cost Function}

Various literatures have discussed the concept of efficiency. Koopman (1951: p.60) defines efficiency as a condition of increase in an output, which results in a decrease of other outputs in the least amount as well as an increase of at least one input. Meanwhile, Coolin (1999: p.102) defines efficiency as the working as well as the producing ability in the proper ways and the precise results. Based on this understanding, Coelli et al. (2005) conclude that being technically efficient is when producers produce the same product with less input or use the same input to produce more products. In contrast, being technically inefficient can be defined as the failure to obtain maximum possible output with the available input levels (Amsler et al., 2009).

Efficiency has three functional approaches (Kumbhakar and Lovell, 2000), namely the production efficiency generating the technical efficiency score, cost efficiency, and profit efficiency. Farrell (1957) defines the production efficiency as how the firm producing an output as large as possible from a given set of input. Production efficiency is derived from production function and is measured through the production frontier (Kumbhakar and Lovell, 2000). Meanwhile, cost efficiency is derived from cost function and is measured through the cost frontier whenever price data are available and firm is assumed of minimizing cost (Coelli et al., 2005). The difference between technical and cost efficiency related to its frontier is in the pattern of converging to the frontier. Technical efficiency will be more efficient only if the score is improved from zero to the unitary level, one. In contrast, the cost efficiency is possible to start from infinite point converging into the frontier in the unitary level. This occurs because the technical efficiency of production has its own maximum capacity of input in producing the output, while cost of production can be allocated as much as possible though it will tremendously enlarge the rate of inefficiency. Therefore, the cost inefficiency score ranges from infinite to one.

The estimation of cost frontier is functioned as the estimation among variables composed the total cost (Coelli et al., 2005). There are two convenient models to demonstrate the relationship each variables, Cobb Douglas and Transcendental Logarithmic (Translog). The cost function of Cobb Douglas is following equation:

$$
\ln C_{i}=\beta_{0}+\sum_{n=1}^{N} \beta_{n} \ln w_{n i}+\sum_{m=1}^{M} \emptyset_{m} \ln q_{m i}+v_{i}+u_{i}
$$

where $c_{i}$ is the observed cost of firm $\mathrm{i} ; w_{i}$ is the $n$-th input price; $q_{m i}$ is the $m$-th output; $v_{i}$ is a random error variable; $u_{i}$ is a non-negative variable representing inefficiency. Translog cost function is the following.

$$
\begin{gathered}
y_{i}^{*}=\beta_{0}+\theta t_{i}+\beta_{2} z_{2 i}+\beta_{3} z_{3 i}+\beta_{q} l n q_{i}+\beta_{12} z_{12 i}+\beta_{13} z_{13 i}+\beta_{23} z_{23 i}+\beta_{q 2} z_{q 2 i} \\
+\beta_{q 3} z_{q 3 i}+\beta_{q q}\left(L n q_{i}\right)^{2}+v_{i}+u_{i}
\end{gathered}
$$

where $y_{i}^{*}$ is $\ln c_{i}-\ln w_{1 i^{\prime}} z_{m i}$ is equal to $\ln w_{m i}-\ln w_{i i^{\prime}} z_{n m i}$ is equal to $\ln w_{n i} \ln$ $w_{m i}-0,5\left(\ln w_{n i}\right)^{2}-0,5\left(\ln w_{m i}\right)^{2} ;$ and $z_{q n i}$ is equal to $\ln q_{i}\left(\ln w_{n i}-\ln w_{1 i}\right)$. According to the equation (2), Translog cost function is more flexible in illustrating the entire variables composed of cost, such as interaction between labor and capital. 


\subsection{Convergence}

Convergence theory was developed through various utilizations. However, this concept was started by Solow (1956) for the economic growth phenomenon. Solow assumes that the per capita of economic growth tends to be contrary to the level of initial output or income level of a person (Ramsey, 1928). This assumption derives from the theory of convergence, which originally derives from neoclassical theory (Solow, 1956). Subsequently, Baumol (1986), followed by Barro and Sala-i-Martin (1992) find that the poorer countries grow faster than richer countries; hence, the per capita income will be eradicated. Although Baumol (1986) find diverging results from the data set since World War II (from 1870 to 1979). Barro and Sala-iMartin (1992) successfully discovered the convergence of economic growth of 98 countries and the trend to obtain the steady-state.

Distinguishing the pattern of convergence of some countries, Barro et al. (1991) propose two concepts of convergence, $\beta$-convergence, and $\sigma$-convergence which are explained for cross-section circumstances (Weill, 2009). $\beta$-convergence implies that the countries with a lower initial level have faster growth rates than those with a higher initial level or there is a catching-up effect of lower level countries. Meanwhile, $\sigma$-convergence explains the dispersion of growth among crosssection and detects the speed of each country's rate converging to the average level of the group of countries. The $\sigma$-convergence is not absent if the dispersion of cross-section diminishes overtime (Quah, 1996). This study will only test the $\beta$-convergence.

Following the test of growth convergence, the efficiency convergence was also developed with various definitions. Barro and Sala-i-Martin (1992) and Mas et al. (1998) started the test of convergence of efficiency score by postulating two alternative ways to detect efficiency convergence implying the reduction in inequalities: (1) the dispersion basis of statistics; and (2) the catching up effect of regions which have lower efficiency levels experiencing greater growth of efficiency along the year. However, since the concept of efficiency was proposed by Farrell (1957), efficiency convergence was indirectly stated by Battese and Coelli (1995) in their research which states that there was a positive trend of efficiency along the time variable to obtain the frontier. However, these concepts were distinguished with the convergence theory of Barro and Sala-i-Martin (1992) which analyzes disparity reduction among the countries. The study by (Battese, 1992) was carried on by Kneller and Stevens (2003) and Kumbhakar and Wang (2005) by adding the ratio of capital and labor in the beginning period as parameter of convergence and testing what the trend of efficiency along the time variable was.

\section{METHODOLOGY}

\subsection{Stochastic Frontier Analysis (SFA)}

There are two parametric methodologies to measure efficiency of banking, namely the SFA and the DFA. Fries and Taci (2005) distinguish these methods by the inefficiency parameter from each bank and its random error specification. SFA as a deterministic approach uses the frontier to examine the estimated efficiency and this frontier will be the indicator of an optimum efficiency condition (Coelli et al., 2005). 
The SFA accommodates two types of efficiency, production technique, and cost efficiency. Measuring cost efficiency of banking with SFA is a proper way, instead of measuring its technical efficiency. Berger and DeYoung (1997) contend that the concept of the cost efficiency is suitable for a financial institution due to the banking base which uses economic optimization as the reaction of price market and competitiveness, not merely technological utilization. Hence, cost efficiency measures the minimum expenditure which needs to produce an amount of output, with a certain price, as well as specific technology.

The SFA provides the test of determinants, called efficiency effects, towards dependent variables (Coelli et al., 2005). Instead of executing two-step way by measuring technical efficiency and then regressing it towards determinants (such as DEA processed with TOBIT), SFA accommodates one-step way to detect the determinants. Therefore, all observed variables which correlate with efficiency could be directly investigated.

The most common output-oriented measure of efficiency is the ratio of observed output to the corresponding stochastic frontier output in the following formula.

$$
C E_{i}=\frac{q_{i}}{\exp \left(x_{i}^{\prime} \beta+v_{i}\right)}=\frac{\exp \left(x_{i}^{\prime} \beta+v_{i}-u_{i}\right)}{\exp \left(x_{i}^{\prime} \beta+v_{i}\right)}=\exp \left(-u_{i}\right)
$$

Random error is assumed symmetric, while efficiency scores are a half-normal distribution. Both of these parameter are assumed to be independently distributed.

The fixed effect model can be estimated in a standard regression framework using dummy variables (Coelli et al., 2005). Nevertheless, unfortunately, the estimated model can merely be used to calculate efficiency relative to the most efficient firm in the sample. Hence, random effect model which can use either the least square or maximum likelihood technique is more suitable for SFA.

Maximum Likelihood (ML) is used in the SFA. This approach involves making stronger distributional assumption concerning $u_{i} \mathrm{~s}$ (Coelli et al., 2005) such as a half-normal distribution postulated by Aigner et al. (1977) consider the truncated normal distribution. Random error is assumed to be symmetrically distributed $\left(v_{i}\right.$ iidN $\left(0, \sigma_{\mathrm{v}}^{2}\right)$ while inefficiency index $\left(u_{i}\right)$ is assumed to be independently a half normal distribution $\left(u_{i} i i d N^{+}\left(0, \sigma_{u}^{2}\right)\right)$ due to the non-negative assumption of efficiency score. The score of cost efficiency will range from 1 to infinity, 1 means that the total cost is fully efficient while getting further of 1 means more inefficient.

\subsection{Data and Model Specification}

This research utilizes secondary data of 20 Indonesian conventional banks listed in the Indonesia Stock Exchange (IDX). The data set is obtained from the annual financial report of the banking companies from 2008 to 2017. This focus on commercial banks instead of rural banks is due to the larger proportion of disbursed loans which reached approximately $98.33 \%$ of the total fund ${ }^{4}$.

4 According to the Indonesia Banking Statistics 2017 published by the Financial Service Authority of Indonesia 
The decision on choice of variables follows the literature. In terms of choosing the variable of banking efficiency, there are two approaches. The first is the intermediation approach, initiated by Sealey and Lindley (1977) in which the inputs include the entire cost, such as operational cost and interest cost, to gain the revenues from intermediation process (Berger and Humphrey, 1991). The second is a production approach in which physical inputs, such as capital and labor, are taken into consideration (Kuussaari and Vesala, 1995).

This study uses the intermediation approach because it is more suitable for evaluating the performance of a financial institution (Berger and Humphrey, 1991). This study utilizes inputs, namely the price of labor which is the ratio of the personnel expenses and total labor (Margono et al., 2010), price of capital which is the ratio of the cost of administration and general and fixed assets (Al-jarrah and Molyneux, 2006), and price of fund which is the ratio of the interest expense and total deposit. The only output of this study is the price of loans which is the ratio of the interest income and total loans. These variables are based on the studies of Nuryartono et al. (2012) and Gallizo (2011). The cost model is shown in the following equation which uses the Translog function (Coelli, 2003).

$$
\begin{array}{r}
L n\left(\frac{T C_{i t}}{T A_{i t}}\right)=\beta_{0}+\beta_{1}(\ln (P L O A N))+\beta_{2}(\ln (P L A B))+\beta_{3}(\ln (P C A P))+\beta_{4}(\ln (P F U N D))+\beta_{5}(\mathrm{~T})+ \\
0,5 \beta_{6}\left(\ln (P L O A N)^{2}\right)+0,5 \beta_{7}\left(\ln (L A B)^{2}\right)+ \\
0,5 \beta_{8}\left(\ln (P C A P)^{2}\right)+0,5 \beta_{9}\left(T^{2}\right)+0,5 \beta_{10}\left(\ln (P F U N D)^{2}\right)+\beta_{11}(\ln (P L O A N . P L A B))+ \\
\beta_{12}(\ln (P L O A N . P C A P))+\beta_{13}(\ln (P L O A N . P F U N D))+\beta_{14}(\ln (P L A B . P C A P))+ \\
\beta_{15}(\ln (P L A B . P F U N D))+\beta_{16}(\ln (P C A P . P F U N D))+\beta_{17}(\ln (P L O A N . T))+\beta_{18}(\ln (P L A B . T))+ \\
\beta_{19}(\ln (P L A B . T))+\beta_{20}(\ln (P C A P . T))+v_{i t}+u_{i t}
\end{array}
$$

An alternative function, Cobb Douglas, is also utilized to simply illustrate the correlation among variables. Cobb Douglas is a part of Translog which neglects $\beta_{5}$ $\beta_{6}, \beta_{7}, \beta_{8}, \beta_{9}, \beta_{10}, \beta_{11}, \beta_{12}, \beta_{13}, \beta_{14}$.

$$
\begin{aligned}
\operatorname{Ln}\left(\frac{T C_{i t}}{T A_{i t}}\right)= & \beta_{0}+\beta_{1}(\ln (P L O A N))+\beta_{2}(\ln (P L A B))+\beta_{3}(\ln (P C A P))+\beta_{4}(\ln (P F U N D)) \\
& +\beta_{5}(T)+v_{1}+u_{1}
\end{aligned}
$$

where $T C$ is total cost including interest cost and other operating cost, $T A$ is total assets, PLOAN is price of loans, PLAB is price of labor, PCAP is price of capital, PFUND is price of funding, and $T$ is time trend.

The decision of the utilization of cost function can use Likelihood test. The following likelihood ratio test is utilized to select the appropriate cost function, either Translog or Cobb Douglas:

$$
\lambda=-2\left[\lambda\left(H_{0}\right)-\lambda\left(H_{1}\right)\right]
$$

where $\lambda(H 0)$ and $\lambda(H 1)$ is the value of Log Likelihood of each null hypothesis (Cobb Douglas) and alternative hypotheses (Translog). Likelihood Ratio tests are trying to choose the best cost function used to estimate technical inefficiency. This method considers $\lambda$ as a parameter by seeing Log Likelihood value in each 
cost function. If $\lambda$ is greater than $\chi 2$ table, the null hypotheses are rejected, thus Translog should be empowered.

For the indicated determinants contained in $u_{i,}$, called TE Effect, there is only time trend which precedes Battese and Coelli (1995) to detect inefficiency direction, converge or divergence towards cost frontier.

$$
u_{i t}=\delta_{0}+\delta_{1}(\mathrm{t})+W_{i t}
$$

where $u_{i t}$ is inefficiency index, $t$ is time trend and $W_{i t}$ is error term.

The next step is about testing the inefficiency convergence. This test strengthens the convergence theory of Barro and Sala-i-Martin (1992). For a specific model of banking case, this study follows the study of Weill (2009).

$$
\operatorname{Ln}\left(I N E F F_{q t}\right)-\operatorname{Ln}\left(I N E F F_{q, t-1}\right)=\alpha+\beta \operatorname{Ln}\left(I N E F F_{q, t-1}\right)+\varepsilon_{q t}
$$

where $0<\beta<1$, INEFF is the rate of technical inefficiency, $\alpha$ and $\beta$ are parameters estimated, $\varepsilon_{q t}$ is an error term. Beta convergence occurs when the value of $\beta$ is negative. The speed of convergence is represented by the coefficient of $\beta$ in which the greater the value, the quicker the convergence trend.

As well as its determinants which are macroeconomic variables, namely inflation, GDP as well as its decomposition based on the expenditure approach (household consumption, investment, and net exports) in which all of these are influencing convergence inefficiency (Becerril-Torres et al., 2010). This research does not include government expenditure as the data considered here must consist not only of state-owned enterprises but also private banks.

$$
\begin{aligned}
\operatorname{Ln}\left(I N E F F_{i t}\right)-\operatorname{Ln} & \left(I N E F F_{i, t-1}\right) \\
& =\varphi_{0}+\varphi_{1} \operatorname{Ln}\left(I N E F F_{i, t-1}\right)+\varphi_{2}\left(I N F_{i t}\right)+\varphi_{3}\left(\operatorname{Ln}(G D P)_{i t}\right) \\
& +\varphi_{4}\left(\operatorname{Ln}(\text { EXCHANGE })_{i t}\right)+\varphi_{5}\left(\operatorname{Ln}(\operatorname{CONEX})_{i t}\right)+\varphi_{6}\left(\operatorname{Ln}(I N V E S T)_{i t}\right) \\
& +\varphi_{7}\left(\operatorname{Ln}(N E T E X P O R T)_{i t}+\varepsilon_{q t}\right.
\end{aligned}
$$

where INEFF ${ }_{i t}$ is the inefficiency score in the current year, INEFF $F_{i, t-1}$ is the inefficiency score in the previous year. The ratio of these two parameters is to measure the growth of inefficiency score which implies convergence. The parameter of $\phi_{1}$ indicates the inefficiency convergence. If the sign is negative, convergence occurs. INF is the rate of inflation. EXCHANGE is exchange rate of rupiah throughout USD in the end of the year. GDP is the nominal gross domestic product (USD), HOUSECON is household consumption associated with GDP of expenditure approach, INVEST is investment which has been proxy to Gross Fixed Capital Formation (GFCF), and NET EXPORT is total export minus total import. Regression is executed with panel regression of Random Effect Model following the Hausman test. This analysis will be presented in four parts to compare the speed of convergence in each year. 


\section{RESULTS AND ANALYSIS}

The first step of estimating the cost efficiency score is determining the cost function. The LLR test based on the equation (6) is necessary to ascertain the proper utilized function. The test of LLR in this study is comparing Translog and Cobb Douglas cost function which is specified in the equation (4) and (5) respectively. The test result of $\lambda$ is 37.26 which is greater than the $\gamma^{2}$ table by the $1 \%$ significant level. Therefore, this study accepts Translog as cost function for further analysis. The Maximum Likelihood results are shown in Table 1.

Table 1.

Maximum Likelihood Results

\begin{tabular}{|c|c|c|c|}
\hline Parameter & Variable & Coefficient & Standard Error \\
\hline$\beta 0$ & Constant & -11.076 & $1.006^{* * *}$ \\
\hline$\beta 1$ & Loan & 6.408 & $0.978^{* * *}$ \\
\hline$\beta 2$ & Labor & 1.418 & $0.203^{* * *}$ \\
\hline$\beta 3$ & Capital & -0.018 & 0.488 \\
\hline$\beta 4$ & Fund & -1.219 & 0.927 \\
\hline$\beta 5$ & Time & 0.405 & $0.160^{* * *}$ \\
\hline$\beta 6$ & 0,5 (Loan2) & 0.18 & $0.054^{* * *}$ \\
\hline$\beta 7$ & 0,5 (Labor2) & -0.089 & $0.018^{* * *}$ \\
\hline$\beta 8$ & 0,5 (Capital2) & 0.041 & $0.020^{* *}$ \\
\hline$\beta 9$ & 0,5 (Fund2) & 0.269 & $0.142^{*}$ \\
\hline$\beta 10$ & 0,5 (Time2) & 0.007 & $0.002^{* * *}$ \\
\hline$\beta 11$ & Loan x Labor & -0.365 & $0.054^{* * *}$ \\
\hline$\beta 12$ & Loan x Capital & 0.134 & $0.042^{* * *}$ \\
\hline$\beta 13$ & Loan $x$ Fund & -0.186 & 0.126 \\
\hline$\beta 14$ & Labor x Capital & 0.032 & 0.029 \\
\hline$\beta 15$ & Labor $x$ Fund & 0.13 & $0.048^{* * *}$ \\
\hline$\beta 16$ & Capital x Fund & 0.086 & $0.050^{*}$ \\
\hline$\beta 17$ & Loan $x$ Time & 0.085 & $0.014^{* * *}$ \\
\hline$\beta 18$ & Labor x Time & -0.021 & $0.010^{* *}$ \\
\hline$\beta 19$ & Capital x Time & 0.002 & 0.004 \\
\hline$\beta 20$ & Fund $x$ Time & -0.043 & $0.014^{* * *}$ \\
\hline \multicolumn{4}{|l|}{ Inefficiency Effect } \\
\hline$\delta 0$ & Constant_ & 0.152 & $0.030^{* * *}$ \\
\hline \multirow[t]{4}{*}{$\delta 1$} & time trend & -0.028 & $0.003^{* * *}$ \\
\hline & 52 & 0.012 & $0.001^{* * *}$ \\
\hline & $\gamma$ & 0.021 & $0.003^{* * *}$ \\
\hline & kehood & 159.468 & \\
\hline
\end{tabular}

Where : ***: significant at $1 \% ;{ }^{* *}$ :significant at $5 \% ;{ }^{*}$ : significant at $1 *$ 
According to the results, the parameters of gamma and sigma-square are both significant at the $1 \%$ level with the coefficient $2.1 \%$ and $1.3 \%$ respectively. This result means the aforementioned specification in this study is appropriate for profound analysis. For the main variables, this study found positive signs of loan, labor, and time. Capital and fund variables by contrast have negative influences on total cost though the rate is lowly determining toward the cost. Hence, it is not quite significant. Subsequently, the only determinant of inefficiency effect, time trend, has a negative sign which means the inefficiency scores of observed banks converge into the frontier along the time.

The following step is testing the inefficiency convergence by using the equation (5) with Random Effect Model. This result is divided into four parts which consist of the convergence of 2008-2017, 2008-2010, 2011-2013, and 2014-2017. The results are shown on the Table 2.

Tabel 2.

The Test of Inefficiency Result

\begin{tabular}{lcccccccc}
\hline \multirow{2}{*}{ Parameter } & \multicolumn{2}{c}{$2008-2017$} & \multicolumn{2}{c}{ 2008-2010 } & \multicolumn{2}{c}{ 2011-2013 } & \multicolumn{2}{c}{ 2014-2017 } \\
\cline { 2 - 9 } & Coeff & SE & Coeff & SE & Coeff & SE & Coeff & SE \\
\hline Constant & -0.003 & $0.005^{* * *}$ & -0.017 & $0.003^{* * *}$ & 0.002 & $0.0007^{* * *}$ & 0.0006 & $0.0001^{* * * *}$ \\
$\begin{array}{l}\text { Ln_Inefficiency } \\
\text { (t-1) }\end{array}$ & -0.262 & $0.009^{* * * *}$ & -0.093 & $0.032^{* * *}$ & -0.417 & $0.017^{* * *}$ & -0.486 & $0.023^{* * *}$ \\
\hline
\end{tabular}

Where: ${ }^{* * *}$ : significant at $1 \% ;{ }^{* *}$ :significant at $5 \%{ }^{*}$ : significant at $1{ }^{*}$

According to Table 2, during 2008 to 2017, inefficiency occurs to the speed of convergence $26.2 \%$. Meanwhile, the lowest speed of convergence exists between 2008 to 2010 by $9.3 \%$. Following this range of time, the speed of convergence rises respectively in 2011-2013 and 2014-2017 with the rate $41.7 \%$ and $48.6 \%$. These results suggest that at the beginning of the GFC, Indonesian banks had been shocked in terms of performance. However, fortunately, a major improvement was immediately executed and significantly reduced the inefficiency rate. Accordingly, Basri (2013) states that the readiness of Indonesia in dealing with 2008 crisis was much better than in 1998. Therefore, even though in the end of 2008 banks were temporarily shocked due to GFC, but they successfully survived and their efficiency had been enhanced.

The following are the results of the test of determinants to the growth of inefficiency. The inefficiency results of convergence mean that the trend can detect the determinants through the growth of inefficiency. This was proposed by Becerril-Torres et al. (2010), which detects the influence of infrastructure to the efficiency convergence through measuring its growth as dependent variable. Hence, this study can follow the similar model by using the random effects model. The results are shown in Table 3. 
Table 3.

The Random Effect Model of Inefficiency Growth Determinants

\begin{tabular}{llll}
\hline \multirow{2}{*}{\multicolumn{1}{c}{ Parameter }} & \multicolumn{2}{c}{ Coeff } & SE \\
\cline { 2 - 4 } & \multicolumn{2}{c}{0.27 -2017 } \\
\hline Constant & -0.112 & $0.026^{* * *}$ \\
Ln_Inefficiency & 0.0002 & $0.000^{* *}$ \\
Inflation & -0.011 & $0.003^{* * *}$ \\
Ln_GDP & 0.073 & $0.003^{* * *}$ \\
Ln_Exchange Rate & -0.0005 & 0 \\
Growth of Consumption & & \\
Expenditure & 0.0003 & 0 \\
Growth of Investment & -0.00002 & $0.000^{* * *}$ \\
Growth of Net Export & & \\
\hline
\end{tabular}

Where : ***: significant at $1 \%{ }^{* *}$ :significant at $5 \%{ }^{*}$ : significant at $1^{*}$

It is found that there is a significant influence of some macroeconomic indicators. Inflation is allegedly influencing the positive direction with the growth of inefficiency and significant at the $5 \%$ level. This result implies that the inflation will grow the inefficiency of the banks. Huybens and Smith (1998) contend that the relationship between inflation and banking performance results from credit market frictions. As inflation escalates, both banking activity and capital formation are reduced. The rationing of credit would be more cautious due to a failure that might occur. Consequently, the disbursed loans are decreasing while the allocations of entire expenses, such as the cost of fund, the cost of labor, as well as the cost of general and administration, are constant. Moreover, assets in general and the real rate of return might drive down cohering to the trimmed real return. Therefore, inefficiency will be aggravated by banking stability performance.

GDP is also negatively and significantly contributing to the rate of inefficiency at a rate of $1.1 \%$. Banking companies respond to the rate of GDP as the main macroeconomic indicator through several channels, such as net interest income, loan interest improvement, and operating costs ((Calza et al., 2006), (Jiménez et al., 2010), (Bolt et al., 2012), and (Combey and Togbenou, 2017)). The increase in GDP is portrayed as raising household income, consumption enlargement, as well as the money spending to the real sector. This circumstance beneficially involves banks as financial institution in the growth of deposits. Moreover, greater amount of GDP will significantly enlarge the loans and deposits of banks, thus it will be utilized optimally to reduce the banking inefficiency growth.

The indifferent pattern of GDP also is associated with the growth in net export. As a part of expenditure approach of GDP, net exports significantly support the inefficiency growth with negative signs, meaning that the higher growth of net exports will improve the bank performance. This finding, however, shows a small influence due to the indirect transmission between net exports to the bank inefficiency. Nevertheless, the growth of the net exports in some way would implicate directly the economic growth (Balassa, 1978). In the end, it might intervene with bank inefficiency. 
The highest contribution of a macroeconomic indicator is the exchange rate which is $7.3 \%$. While Rupiah, the Indonesian currency, depreciates, it directly causes the growth in inefficiency. This means that it contributes to the hampering of inefficiency convergence. The study by Sun and Chang (2011) find a similar result as the exchange rate has the greatest role in interfering with bank performance. They found that the cost of Indonesian banking is the most volatile among the observed countries. As inflation influences the bank inefficiency through various costs, exchange rate is also transmitted into bank expenses. While the exchange rate of certain countries is converging towards other currencies, a country will theoretically increase the interest rate to keep the money restored in these countries. Nevertheless, a trade-off will occur for which debtor borrows the money with nonflat rate. As a result, credit failure might attack intensely and absolutely aggravate the inefficiency of the banks. Therefore, banks should carefully scrutinize and compare the cost and benefit of these circumstances.

The remaining variables namely growth in household expenditure and the growth in investment apparently do not have an incredible distribution towards the growth of inefficiency of the Indonesian banks. This study alleges that there is no direct effect of the consumption expenditure and investment on the inefficiency rate as the net export is statistically significant. Nevertheless, the impact is too low and unable to be analyzed.

The implications of this finding are related to the evaluation of Indonesian bank performance after the GFC. In response to the GFC Bank Indonesia announced policies to tackle these effects (Basri, 2013), such as by providing guarantees to maintain the banking sector's confidence, a social safety net program for the poorest segments to ensure that they not be impacted by the financial crisis, and the last is the quick response towards the monetary instrument, such as interest rate, which was immediately lowered from $9.5 \%$ in November 2008 to $6.5 \%$ by the end of 2009. The last one was a fiscal policy in the form of stimulus up to 6.4 billion USD to ensure there is no economic downturn in all sectors. This entire policy had successfully brought the banking sectors back to being much better balanced than during the 1998 crisis. Hence, the inefficiency convergence occurred from 2008 through 2017.

\section{CONSCLUSION}

The financial crises affecting Indonesia necessitated research aimed at understanding the performance of financial institutions. It is necessary to mitigate and depict the current condition of Indonesia's banking system. This study tests the cost inefficiency convergence of the Indonesian banks and explores the macroeconomic indicators which contribute to it. This study also divides the analysis of convergence into four parts to compare the speed of convergence in each time span. The finding shows that inefficiency convergence occurred from 2008 to 2017, 2008-2010, 2011-2013, and 2014-2017. Nevertheless, the period between 2008-2010 has the lowest speed of inefficiency convergence, which means that banks were slower in the cost management compared to other time periods. This result can be attributed to the GFC. The convergence results proceed to further test the influence of macroeconomic indicators towards the growth of inefficiency 
convergence. The results suggest that inflation and exchange rate significantly influence the inefficiency growth in a positive direction. Other indicators, such as GDP and net exports, negatively contribute to inefficiency growth.

\section{REFERENCES}

Aigner, D., Lovell, C. A. K., \& Schmidt, P. (1977). Formulation and estimation of stochastic frontier production function models. Journal of Econometrics, 6(1), 21-37.

Al-jarrah, I., \& Molyneux, P. (2006). Cost Efficiency, Scale Elasticity and Scale Economies in Arab Banking. Banks and Bank Systems, 1(3), 60-89.

Amsler, C., Lee, Y. H., \& Schmidt, P. (2009). A Survey of Stochastic Frontier Models and Likely Future Developments. Seoul Journal of Economics, 22(1).

Balassa, B. (1978). Exports and economic growth: further evidence. Journal of Development Economics, 5(2), 181-189.

Barro, R. J., Sala-i-Martin, X., Blanchard, O. J., \& Hall, R. E. (1991). Convergence across states and regions. Brookings Papers on Economic Activity, 107-182.

Barro, R. J., \& Xavier, S.-M. (2004). Economic Growth Second Edition. The MIT Press.

Barro, R. J., \& Sala-i-Martin, X. (1992). Convergence. Journal of Political Economy, 100(2), 223-251.

Basri, M. C., \& Siregar, R. Y. (2009). Navigating Policy Responses at The National Level In The Midst Of The Global Financial Crisis: The Experience Of Indonesia. Asian Economic Papers, 8(3), 1-35.

Basri, M. C. (2013). A Tale of Two Crises: Indonesia's Political Economy. JICA-RI Working Paper, (57), 1-37.

Battese, G. E. (1992). Frontier Production-Functions and technical efficiency - A Survey of empirical applications in agricultural-economics. Agricultural Economics, 7, 185-208.

Battese, G. E., \& Coelli, T. (1995). A model for Technical Inefficiency effects in a Stochastic Frontier Production Function. Empirical Economics, 20, 325-332.

Baumol, W. J. (1986). Productivity Growth, Convergence, and Welfare: What the Long-run Data Show. American Economic Review, 76(5), 1072-1085.

Becerril-Torres, O. U., Álvarez-Ayuso, I. C., \& Del moral-Barrera, L. E. (2010). Do infrastructures influence the convergence of efficiency in Mexico? Journal of Policy Modeling, 32(1), 120-137.

Berger, A. N., \& DeYoung, R. (1997). Problem loans and cost efficiency in commercial banks. Journal of Banking and Finance, 21(6), 849-870.

Berger, A. N., \& Humphrey, D. B. (1991). The dominance of inefficiencies over scale and product mix economies in banking. Journal of Monetary Economics, 28(1), 117-148.

Bolt, W., de Haan, L., Hoeberichts, M., van Oordt, M. R. C., \& Swank, J. (2012). Bank profitability during recessions. Journal of Banking and Finance, 36(9), 2552-2564.

Calza, A., Manrique, M., \& Sousa, J. (2006). Credit in the euro area: An empirical investigation using aggregate data. Quarterly Review of Economics and Finance, 46(2), 211-226.

Casu, B., \& Girardone, C. (2010). Integration and efficiency convergence in EU banking markets. Omega, 38(5), 260-267. 
Casu, B., \& Molyneux, P. (2003). A comparative study of efficiency in European banking. Applied Economics, 35(17), 1865-1876.

Coelli, T. (Ed.). (2003). A Primer on Efficiency Measurement for Utilities and Transport Regulators (Vol. 953). World Bank Publications.

Coelli, T. J., Rao, D. S. P., O’Donnell, C. J., \& Battese, G. E. (2005). An introduction to efficiency and productivity analysis. Springer Science \& Business Media.

Cole, D. C., \& Slade, B. F. (1998). Why Has Indonesia's Financial Crisis Been so Bad? Bulletin of Indonesian Economic Studies, 34(2), 61-66.

Collin, P. H. (2010). Dictionary of Banking and Finance: Over 9,000 Terms Clearly Defined. Great Britain: Peter Coolin Publishing

Combey, A., \& Togbenou, A. (2017). The Bank Sector Performance and Macroeconomics Environment: Empirical Evidence in Togo. International Journal of Economics and Finance, 9(2), 180.

Farrell, M. J. (1957). The Measurement of Productive Efficiency. Journal of the Royal Statistical Society. Series A (General), 120(3), 253-290

Fried, H. O., Schmidt, S. S., \& Yaisawarng, S. (1999). Incorporating the Operating Environment into a Nonparametric Measure of Technical Efficiency. Journal of Productivity Analysis, 12(3), 249-267.

Fries, S., \& Taci, A. (2005). Cost efficiency of banks in transition: Evidence from 289 banks in 15 post-communist countries. Journal of Banking $\mathcal{E}$ Finance, 29(1), 55-81.

Gallizo, J. L., Moreno, J., \& Pop, I. I. (2011). Banking efficiency and European integration. Implications of the banking reform in Romania. Annales Universitatis Apulensis: Series Oeconomica, 13(2), 432.

Hadad, M. D., Hall, M. J. B., Kenjegalieva, K. A., Santoso, W., \& Simper, R. (2011). Banking efficiency and stock market performance:an analysis of listed Indonesian banks. Review of Quantitative Finance and Accounting, 37(1), 1-20.

Huybens, E., \& Smith, B. D. (1998). Financial market frictions, monetary policy, and capital accumulation in a small open economy. Journal of Economic Theory, 81(2), 353-400.

Jiménez, G., Ongena, S., Peydró, J. L., \& Saurina Salas, J. (2010). Credit supply: Identifying balance-sheet channels with loan applications and granted loans. Working Paper No. 1179

Kneller, R., \& Stevens, P. A. (2003). The specification of the aggregate production function in the presence of inefficiency. Economics Letters, 81(2), 223-226.

Kumbhakar, S. C., \& Lovell, C. A. K. (2000). Stochastic Frontier Analysis. Cambridge : University Press Cambridge.

Kumbhakar, S. C., \& Wang, H. J. (2005). Estimation of growth convergence using a stochastic production frontier approach. Economics Letters, 88(3), 300-305.

Kuussaari, H. and Vesala, J. (1995). The efficiency of Finnish banks in producing payment and account transactions, Working Paper, Bank of Finland.

Koopmans, T. C. (1951). Activity Analysis of Production and Allocation. New York: Waley

Mas, M., Maudos, J., Pérez, F., \& Uriel, E. (1998). Public capital, productive efficiency and convergence in the Spanish regions (1964-93). Review of Income and Wealth, 44(3), 383-396.

Margono, H., Sharma, S. C., \& Melvin, P. D. (2010). Cost efficiency, economies of 
scale, technological progress and productivity in Indonesian banks. Journal of Asian Economics, 21(1), 53-65.

Miller, S. M., \& Noulas, A. G. (1996). The technical efficiency of large bank production. Journal of Banking and Finance, 20(3), 495-509.

Nuryartono, N., Anggraenie, T., \& Firdaus, R. S. (2012). Efficiency level of BPR: Study of stochastic frontier analysis with an approach of time varying decay. International Research Journal of Finance and Economics, 85(January), 6-13.

Olson, D., \& Zoubi, T. (2017). Convergence in bank performance for commercial and Islamic banks during and after the Global Financial Crisis. Quarterly Review of Economics and Finance, 65, 71-87.

Patten, R. H., Rosengard, J. K., \& Johnston, D. E. (2001). Microfinance success amidst macroeconomic failure: The experience of bank Rakyat Indonesia during the East Asian crisis. World Development, 29(6), 1057-1069.

Quah, D. (1996). Empirics for economic growth and convergence. European Economic Review, 4, 1353-1375.

Ramsey, F. P. (1928). A mathematical theory of saving. The economic journal, 38(152), 543-559.

Sealey, C. W. J., \& Lindley, J. T. (1977). Inputs, Outputs, and a Theory of Production and Cost at Depository Financial Institutions. Journal of Finance, 32(4), 12511266.

Solow, R. M. (1956). A Contribution to the Theory of Economic Growth. Source: The Quarterly Journal of Economics, 70(1), 65-94.

Sun, L., \& Chang, T. P. (2011). A comprehensive analysis of the effects of risk measures on bank efficiency: Evidence from emerging Asian countries. Journal of Banking and Finance, 35(7), 1727-1735.

Sufian, F., \& Habibullah, M. S. (2010). Assessing the impact of financial crisis on bank performance: Empirical evidence from Indonesia. ASEAN Economic Bulletin, 245-262.

Weill, L. (2009). Convergence in banking efficiency across European countries. Journal of International Financial Markets, Institutions and Money, 19(5), 818-833.

Zhang, T., \& Matthews, K. (2012). Efficiency convergence properties of Indonesian banks 1992-2007. Applied Financial Economics, 22(17), 1465-1478. 
This page is intentionally left blank 